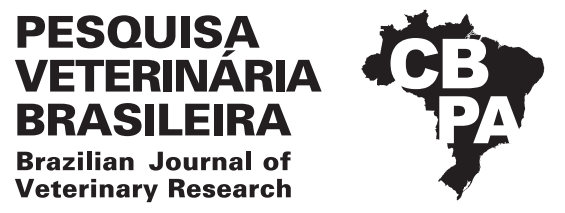

Pesq. Vet. Bras. 38(11):2029-2036, novembro 2018 DOI: 10.1590/1678-5150-PVB-5786

Original Article

Animais de Produção/Livestock Diseases

ISSN 0100-736X (Print)

ISSN 1678-5150 (Online)

\title{
Frequency of Staphylococcus aureus virulence genes in milk of cows and goats with mastitis ${ }^{1}$
}

\author{
Atzel C. Acosta ${ }^{2 *}$, Pollyanne Raysa F. Oliveira², Laís Albuquerque², \\ Isamara F. Silva ${ }^{3}$, Elizabeth S. Medeiros ${ }^{2}$, Mateus M. Costa ${ }^{3}$, \\ José Wilton Pinheiro Junior ${ }^{2}$ and Rinaldo A. Mota ${ }^{2}$
}

\begin{abstract}
Acosta A.C., Oliveira P.R.F., Albuquerque L., Silva I.F., Medeiros E.S., Costa M.M., Pinheiro Junior J.W. \& Mota R.A. 2018. Frequency of Staphylococcus aureus virulence genes in milk of cows and goats with mastites. Pesquisa Veterinária Brasileira 38(11):2029-2036. Laboratório de Bacterioses dos Animais Domésticos, Departamento de Medicina Veterinária, Universidade Federal Rural de Pernambuco, Rua Dom Manoel de Medeiros s/n, Dois Irmãos, Recife, PE 52171-900, Brazil. E-mail: acabad80@gmail.com

The present study determined the frequency of Staphylococcus aureus virulence genes in 2,253 milk samples of cows $(n=1000)$ and goats $(n=1253)$ raised in three different geographical regions of the state Pernambuco, Brazil. The presence of genes of virulence factors associated to adhesion to host cells ( $f n b A, f n b B, c l f A$ and $c l f B$ ), toxinosis (sea, seb, sec, sed, seg, seh, sei, tsst, hla and hlb), and capsular polysaccharide (cap5 and cap8) was evaluated by PCR. A total of 123 and 27 S. aureus strains were isolated from cows' and goats' milk, respectively. The sec and tsst genes were detected exclusively in goats' isolates, while the seh gene was only identified in cows' isolates. The number of toxin genes per strain showed that goats' isolates are likely more toxic than bovines' isolates. The cap 5 genotype predominated in both host species, especially in strains collected from cows raised in the Agreste region. The cap8 genotype is likely more virulent due to the number of virulence genes per strain. The results of the present study demonstrate that $S$. aureus may pose a potential threat to human health in Brazil, and, therefore, these results should support actions related to mastitis control programs.
\end{abstract}

INDEX TERMS: Staphylococcus aureus, virulence genes, milk, cows, goats, mastitis, molecular typing, genotyping, staphylococcal enterotoxin, capsular polysaccharide, cattle, bacterioses.

RESUMO.- [Frequência de genes fatores de virulência de Staphylococcus aureus em leite de vacas e cabras com mastite.] 0 presente estudo determinou a frequência de genes de virulência de Staphylococcus aureus em 2253 amostras de leite, sendo de vacas $n=1000$ e de cabras $n=1253$, procedentes das três regiões geográficas do estado de Pernambuco, Brasil. A presença de genes de fatores de virulência associados à adesão às células hospedeiras ( $f n b A, f n b B, c l f A$ e $c l f B)$, toxinosis (sea, seb, sec, sed, seg, seh, sei, tsst, hla e hlb) e

\footnotetext{
${ }^{1}$ Received on May 17, 2018.

Accepted for publication on May 21, 2018.

${ }^{2}$ Laboratório de Bacterioses dos Animais Domésticos, Departamento de Medicina Veterinária, Universidade Federal Rural de Pernambuco (UFRPE), Rua Dom Manoel de Medeiros s/n, Dois Irmãos, Recife, PE 52171-900, Brazil. *Corresponding author: acabad80@gmail.com

${ }^{3}$ Universidade Federal do Vale do São Francisco (Univasf), Campus Ciências Agrárias, Rod. BR-407 Km 12, Lote 543, Projeto de Irrigação Senador Nilo Coelho, Petrolina, PE 56300-990, Brazil.
}

polissacarídeo capsular (cap5 e cap8) foram avaliadas por PCR. Um total de 123 e 27 cepas de $S$. aureus foram isoladas do leite de vacas e cabras, respectivamente. Os genes sec e tsst foram detectados exclusivamente em isolados de cabras, enquanto o gene seh foi identificado apenas em isolados de vaca. 0 número de genes de toxina por cepa mostrou que os isolados de cabras são potencialmente mais tóxicos do que os isolados obtidos de bovinos. 0 genótipo cap 5 predominou em ambas as espécies hospedeiras, especialmente em cepas coletadas de vacas criadas na região Agreste. 0 genótipo cap8 é potencialmente mais virulento devido ao número de genes de virulência por isolado. Os resultados do presente estudo demonstram que $S$. aureus pode representar uma ameaça potencial para a saúde humana no Brasil e, portanto, estes resultados devem subsidiar ações relacionadas aos programas de controle de mastite. 
TERMOS DE INDEXAÇÃO: Genes, virulência, Staphylococcus aureus, leite, cabras, mastite, tipagem molecular, genotipagem, enterotoxina estafilocócica, polissacarídeo capsular, bovinos, caprinos, bacterioses.

\section{INTRODUCTION}

Intramammary infections (IMI) are the main cause of economic loss in the dairy industry worldwide (Halasa et al. 2007). The average cost of clinical mastitis in high-yielding cows was estimated in $\$ 71$ per cow per year (Bar et al. 2008). Staphylococcus aureus is an important etiological agent of ruminant IMI in Brazil (Mota et al. 2012), and its eradication from dairy cattle and dairy small ruminants has proven to be difficult (Bergonier et al. 2003).

Several characteristics contribute for the pathogenesis and spread of $S$. aureus including virulence factors, the host and the environment (Roberson et al.1998, Barkema et al. 2006). Previous studies suggest that existing phenotypic and genotype diversity between groups of $S$. aureus would make that some of these strains are better adapted to live in hostile environment (Bardiau et al. 2014, 2016). This bacterium can cause a broad range of diseases due to an abundance of virulence factors that facilitate attachment, colonization, tissue invasion, toxinosis, and immune evasion, including adhesion proteins, enterotoxins and capsular polysaccharides (Zecconi et al. 2006, Piccinini et al. 2010).

Adhesion is hypothesized to be a prerequisite and crucial early step for IMI development (Kerro et al. 2002). Two fibronectin-binding proteins (FnBPs), FnBPA and FnBPB, are involved in not only adhesion to cells but also internalization by cells (Garzoni \& Kelley 2009). Other two important adhesion factors involved in the pathogenesis of S. aureus are the clumping factors, ClfA and ClfB (Ní Eidhin et al. 1998, Garzoni \& Kelley 2009).

Staphylococcal enterotoxins (SEs) are an important group of virulence factors. They play a significant role in modulating the host immune response and may contribute to maintaining a suitable environment for colonization. In addition, SEs and toxic shock syndrome toxin 1 (TSST1) are superantigens, which have the ability to stimulate large populations of $\mathrm{T}$ cells that have a particular $\mathrm{V} \beta$ element of the T-cell receptor (Omoe et al. 2003). Other important toxins are hemolysins, which can negatively affect a wide range of host cells including erythrocytes, epithelial cells, endothelial cells, T cells, monocytes and macrophages (Berube \& Wardenburg 2013).

Capsular polysaccharide (cap) is a cell wall bacterial component that protects bacterium from phagocytic uptake and enhances microbial virulence (Sutra et al. 1990). Cap5 and cap8 were the predominant capsular types in $S$. aureus isolated from clinical bovine mastitis in different countries (Gogoi-Tiwari et al. 2015).

The strong pathogenicity of $S$. aureus strains is driven by multifactorial and complex virulence factors. Appropriate molecular typing methods and information about the genetic diversity of $S$. aureus strains in a particular region may contribute to the development of effective strategies for epidemiological control. The present study aimed to determine the frequency of virulence factors genes in $S$. aureus strains isolated from cow and goat herds raised in three different geographical regions of the state of Pernambuco, Brazil.

\section{MATERIALS AND METHODS}

Ethical statement. The present study was approved by the Institutional Animal Care and Use Committee of the School of Veterinary Medicine, Federal Rural University of Pernambuco (Universidade Federal Rural de Pernambuco - UFRPE), under the protocol number 079/2014-CEUA.

Sample collection and presumptive identification of Staphylococcus aureus. The samples were collected from 24 bovine and 13 goat herds raised in three different geographical regions of state of Pernambuco, Brazil: the Atlantic Forest (five bovine and two goat herds), the Agreste (nine bovine and three goat herds), and the Sertão regions (ten bovine and eigth goat herds). The Atlantic Forest region (Paulista, Recife, Camaragibe and Paudalho) has a hot and humid climate, while the Agreste region (Gravatá, Caruaru and Garanhuns) and Sertão region (Sertânia, Custódia, Serra Talhada, Floresta, Salgueiro, Cabrobó, Santa Maria da Boa Vista and Petrolina) both have a semi-arid climate (Fig.1) (Nóbrega et al. 2015).

A total of 1000 and 1253 cows' and goats' milk samples were collected from individual mammary glands (udder quarters for cows or udder halves for goats) after disinfection of the ostium with 70\% ethanol following the recommendations of the National Mastitis Council (National-Mastitis-Council 1999), and transported to the laboratory under refrigeration $\left(4-10^{\circ} \mathrm{C}\right)$.

In cows, subclinical mastitis was diagnosed by the California Mastitis Test (CMT, (Schalm \& Noorlander 1957); while in goats, IMI was defined as the presence of three or more colonies of the same type after primary culture (Pantoja et al. 2009).

Primary culture of milk samples $(10 \mu \mathrm{L})$ was performed in $5 \%$ ovine blood agar plates incubated aerobically at $37^{\circ} \mathrm{C}$ for $72 \mathrm{~h}$. Milk samples were considered contaminated when three or more dissimilar colony types were founded (Hiitiö et al. 2015). The presumptive identification of $S$. aureus was based on the following parameters: Gram-positive cocci, hemolytic on blood agar, catalase positive, and coagulase positive in 4-18h (Zecconi et al. 2006). The S. aureus ATCC 29213 strain was used as positive control.

Confirmation of the presumptive identification of Staphylococcus aureus. Species confirmation was performed by PCR amplification of the nис gene, as previously described by Brakstad et al. (1992). The isolates presumptively identified as $S$. aureus were freshly cultured in brain infusion broth (Merck) and incubated overnight at $37^{\circ} \mathrm{C}$. Subsequently, DNA was extracted using a commercial kit (Promega) following the manufacturer's instructions and stored at $-20^{\circ} \mathrm{C}$. The nuc_F and nuc_R primers, which amplify a single amplicon with an expected size of approximately 296bp (nt 862768863064, HF937103.1), were specifically designed for the present study (Table 1).

PCR testing for virulence factors genes. The primers used for amplification of the virulence factors genes are shown in Table 1. The PCR was performed in $0.2 \mathrm{~mL}$ tubes with a total volume of $25 \mu \mathrm{L}$ containing: PCR buffer $(10 \mathrm{mM}$ Tris- $\mathrm{HCl}, \mathrm{pH} 9.0 ; 50 \mathrm{mM} \mathrm{KCl}$; $0.1 \%$ Triton $\mathrm{X}-100), 1.5 \mathrm{mM} \mathrm{MgCl}_{2}, 250 \mu \mathrm{M}$ each dNTP, $0.5 \mu \mathrm{M}$ each gene-specific primers, $1.5 \mathrm{U}$ Taq DNA polymerase (Promega), 20ng DNA, and distilled water.

PCR conditions for the amplification of the nuc gene and the virulence factors genes were as follows: $94^{\circ} \mathrm{C}$ for $5 \mathrm{~min}$ (initial denaturation), followed by 32 cycles of $94^{\circ} \mathrm{C}$ for $1 \mathrm{~min}$, annealing temperature specific for each fragment (Table 1) for $1 \mathrm{~min}$ and $72^{\circ} \mathrm{C}$ for $1 \mathrm{~min}$, and a final extension of $72^{\circ} \mathrm{C}$ for $5 \mathrm{~min}$. The PCR products were visualized by electrophoresis in $2 \%$ agarose gels stained with Blue Green Loading Dye I (LGC Biotecnologia) and photographed under UV illumination (Molecular Imaging L.PIX Loccus biotecnologia). 

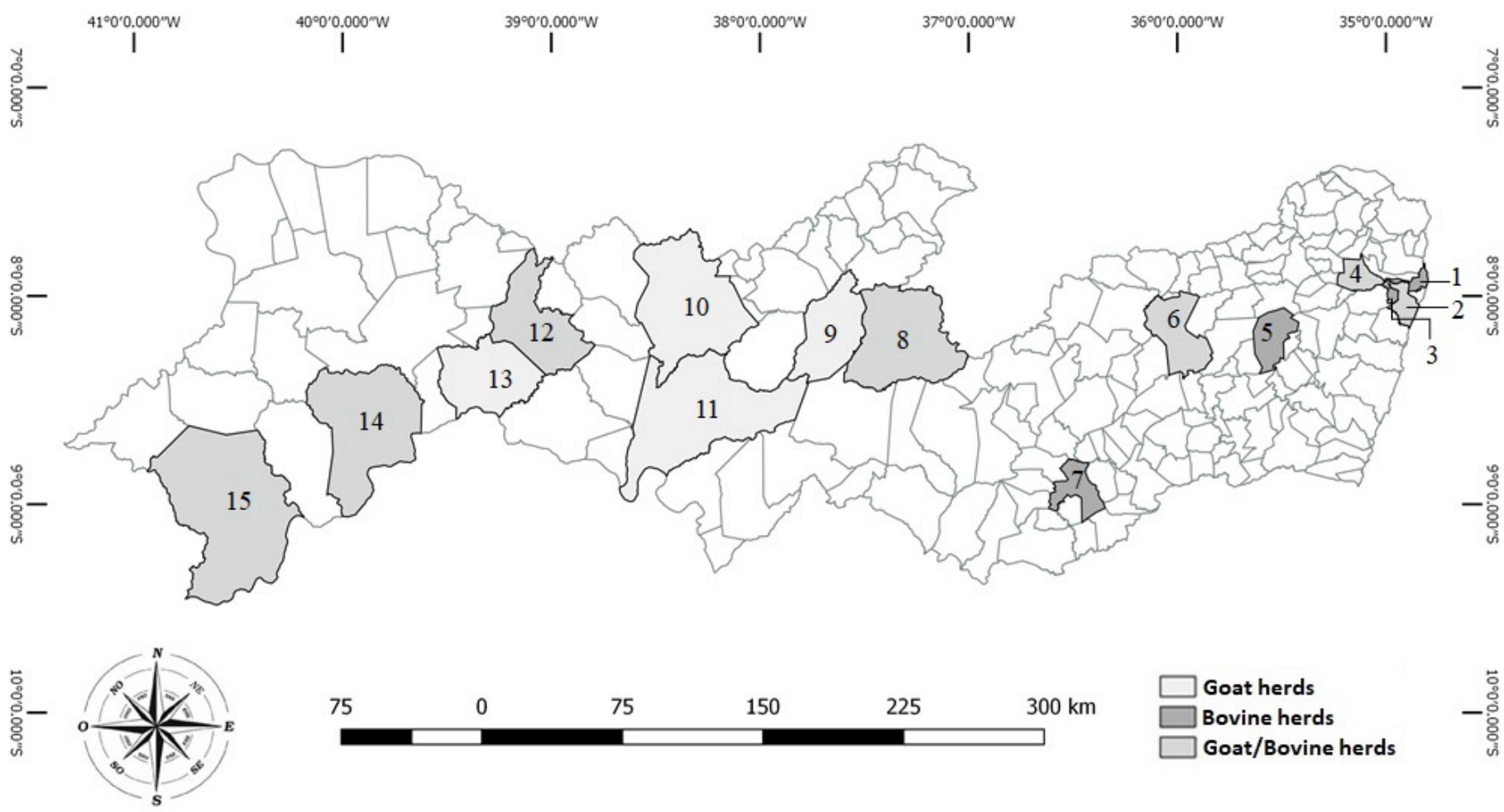

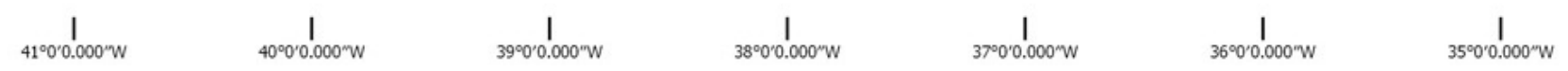

Fig.1. Map of Pernambuco state, Brazil. Distribution of the bovine and goat herds by municipal districts where the Staphylococcus aureus isolates were recovered. Each number represents municipal districts studied of the Atlantic Forest region: Paulista (1), Recife (2), Camaragibe (3), Paudalho (4). Agreste region: Gravatá (5), Caruaru (6), Garanhuns (7). Sertão region: Sertânia (8), Custódia (9), Serra Talhada (10), Floresta (11), Salgueiro (12), Cabrobó (13), Santa Maria da Boa Vista (14), Petrolina (15).

Three amplicons of each virulence factor were purified using the Wizard ${ }^{\circledR}$ SV gel and PCR clean-up system (Promega) and bidirectionally sequenced by standard protocols using the BigDye Terminator v3.1 Cycle Sequencing Kit (Applied Biosystems, Foster City/CA, USA) in an automated sequencer ABI-PRISM 3130 (Applied Biosystems, Foster City/CA, USA). Sequences were aligned using the BioEdit v.7.0.9 software (Hall 1999) and compared with those available in the GenBank database by Basic Local Alignment Search Tool (BLAST- http://blast.ncbi.nlm.nih.gov/Blast.cgi).

Data analysis. Each $S$. aureus strain was considered a experimental unit in all analyses. Gene frequencies were calculated as categorical (binary) variables using Microsoft Excel. The frequency of each virulence gene by host species was compared using the chi-square test (Statgraphics Centurion XVI version 16.1.15, Statpoint Technologies Inc, Warrenton, Virginia). Statistical significance was set at $\mathrm{p}<0.05$ for interpretation and discussion.

\section{RESULTS}

All the Staphylococcus aureus strains isolated in the present study were identified by a genotypic method in which the nuc gene was targeted using specific primers, a well-accepted method that has been used for confirmation of $S$. aureus infection worldwide (Rall et al. 2014). Three amplicons of the nuc gene and each virulence factors ( $f n b A, f n b B, c l f A$, clfB, sea, seb, sec, sed, seg, seh, sei, tsst, hla, hlb, cap5 and cap8) were sequenced, and the partial sequences were confirmed by BLAST searches.

S. aureus strains were recovered from $12.3 \%$ (123/1000) and $2.15 \%(27 / 1253)$ of the cows' and goats' samples, respectively. Table 2 shows the number of strains recovered by geographical area, species and animals' disease status.

Table 3 shows the frequency of the virulence factors by host species and geographical area. The frequency of the virulence factors according to capsular genotyping is shown in Table 4 . The fibronectin-binding proteins, $f n b A$ and $f n b B$, were detected in 141 (94\%) and 122 strains (81.33\%), respectively. S. aureus strains isolated from bovines had a higher frequency of $f n b B(91.06 \%, \mathrm{p}=0.0000)$ than those isolated from goats (Table 3). Strains positive for cap 5 had a higher frequency of the $f n b B$ gene $(88.68 \%, \mathrm{p}=0.0012)$ than cap (-) strains (Table 4).

The clumping factor $\mathrm{A}(\mathrm{clf} A)$ and clumping factor $\mathrm{B}(\mathrm{clf} B)$ were detected in 114 (76\%) and 115 strains (76.67\%), respectively. The lowest frequency of clfA $(62.79 \%, \mathrm{p}=0.0267)$ and $\operatorname{clf} B$ $(65.12 \% \mathrm{p}=0.0323)$ were observed in samples collected from animals raised in the Atlantic forest (Table 3). Cap (-) strains had the lowest frequency of $c l f A(47.06 \%, \mathrm{p}=0.0000)$ (Table 4$)$. $S$. aureus adhesion cannot be explained by the action of a single virulence determinant, and likely a number of factors act in combination during the infective process. 
Table 1. Nucleotide sequences and their characteristics for the Staphylococcus aureus gene-specific oligonucleotide primers used in this study

\begin{tabular}{|c|c|c|c|c|}
\hline $\begin{array}{l}\text { Target } \\
\text { gene }\end{array}$ & Name & $\begin{array}{l}\text { Oligonucleotide sequence } \\
\left(5^{\prime}-3^{\prime}\right)\end{array}$ & $\begin{array}{l}\text { Expected } \\
\text { size }\end{array}$ & At $\left({ }^{\circ} \mathrm{C}\right)^{\mathrm{a}}$ \\
\hline \multirow[t]{2}{*}{ nuc } & nuc_F & GGTTCTGAAGATCCAACAGTAT & $296 \mathrm{pb}$ & 61 \\
\hline & nuc_R & GCTAAGCCACGTCCATATTTA & & \\
\hline \multirow[t]{2}{*}{$f n b A$} & fnbA_F & ACTTCACCTGTCGCCATTAC & $539 \mathrm{pb}$ & 57 \\
\hline & fnbA_R & GCAGTACAAGCACCACAAAC & & \\
\hline \multirow[t]{2}{*}{$f n b B$} & fnbB_F & AGGCGACGGCAAAGATAAA & $317 \mathrm{pb}$ & 60 \\
\hline & fnbB_R & TAGTAACCTGACCACCACCT & & \\
\hline \multirow[t]{2}{*}{$c l f A^{b}$} & clfA_F & GATTCTGACCCAGGTTCAGA & $945 \mathrm{pb}$ & 55 \\
\hline & clfA_R & CTGTATCTGGTAATGGTTCTTT & & \\
\hline \multirow[t]{2}{*}{$c l f B^{b}$} & clfB_F & ATGGTGATTCAGCAGTAAATCC & $880 \mathrm{pb}$ & 55 \\
\hline & clfB_R & CATTATTTGGTGGTGTAACTCTT & & \\
\hline \multirow[t]{2}{*}{$\operatorname{sea}^{c}$} & sea_F & GGTTATCAATGTGCGGGTGG & $102 \mathrm{pb}$ & 65 \\
\hline & sea_R & CGGCACTTTTTTCTCTTCGG & & \\
\hline \multirow[t]{2}{*}{$s e b$} & seb_F & CCCGTTTCATAAGGCGAGTT & $314 \mathrm{pb}$ & 57 \\
\hline & seb_R & ACGTAGATGTGTTTGGAGCTAAT & & \\
\hline \multirow[t]{2}{*}{$\sec ^{c}$} & sec_F & AGATGAAGTAGTTGATGTGTATGG & $451 \mathrm{pb}$ & 57 \\
\hline & sec_R & CACACTTTTAGAATCAACCG & & \\
\hline \multirow[t]{2}{*}{ sed } & sed_F & GTCACTCCACACGAAGGTAATAA & $255 \mathrm{pb}$ & 55 \\
\hline & sed_R & GAGACTTTAGACCCATCAGAAGAA & & \\
\hline \multirow[t]{2}{*}{$\mathrm{see}^{c}$} & see_F & GCTGGAGGCACACCAAATA & $301 \mathrm{pb}$ & 57 \\
\hline & see_R & CATAACTTACCGTGGACCCTTC & & \\
\hline \multirow[t]{2}{*}{ seg } & seg_F & GCCAGTGTCTTGCTTTGTAATC & $491 \mathrm{pb}$ & 56 \\
\hline & seg_R & GAATGCTCAACCCGATCCTAA & & \\
\hline \multirow[t]{2}{*}{ seh } & seh_F & CACATCATATGCGAAAGCAGAAG & $365 \mathrm{pb}$ & 60 \\
\hline & seh_R & CССAAACATTAGCACCAATCAC & & \\
\hline \multirow[t]{2}{*}{ sei } & sei_F & AGGCAGTCCATCTCCTGTATAA & $568 \mathrm{pb}$ & 55 \\
\hline & sei_R & TGCTCAAGGTGATATTGGTGTAG & & \\
\hline \multirow[t]{2}{*}{ tsst $t^{c}$} & tsst_F & ACСССТGTTCССТTATCATC & $326 \mathrm{pb}$ & 57 \\
\hline & tsst_R & TTTTCAGTATTTGTAACGCC & & \\
\hline \multirow[t]{2}{*}{ hla } & hla_F & CTGTAGCGAAGTCTGGTGAAA & $293 p b$ & 62 \\
\hline & hla_R & CGGCCTTATTGGTGCAAATG & & \\
\hline \multirow[t]{2}{*}{$h l b$} & hlb_F & GCCAAAGCCGAATCTAAGAAAG & $495 \mathrm{pb}$ & 60 \\
\hline & hlb_R & ATCATGTCCAGCACCACAA & & \\
\hline \multirow[t]{2}{*}{ cap5 } & cap5_F & CGAACCGATGATTGATGCTATTG & $555 \mathrm{pb}$ & 61 \\
\hline & cap5_R & TGCTATGACTGCACCAGTATTT & & \\
\hline \multirow[t]{2}{*}{ cap8 } & cap8_F & GGAGGAAATGACGATGAGGATAG & $608 \mathrm{pb}$ & 61 \\
\hline & cap8_R & TAGCTTCTGTAGCGGTGAATG & & \\
\hline
\end{tabular}

Table 2. Numbers of strains recovered by regions of the herd, species and disease status of the animal

\begin{tabular}{llccccc}
\hline & & \multicolumn{2}{c}{ Animal species } & & \multicolumn{2}{c}{$\begin{array}{c}\text { Disease status of the } \\
\text { animal }\end{array}$} \\
\cline { 3 - 4 } \cline { 5 - 6 } \cline { 5 - 6 } & & Bovine & Goat & & Subclinical & Clinical \\
\hline Regions of & Atlantic Forest & 36 & 7 & & 34 & 9 \\
the herd & Agreste & 52 & 5 & & 57 & 0 \\
& Sertão & 35 & 15 & & 49 & 1 \\
Animal & Bovine & & & & 120 & 3 \\
species & & & & & 20 & 7
\end{tabular}

Of the 150 strains isolated, 78 (52\%) were positive for one or more SEs genes, which were found in $46.34 \%$ (57/123) and $77.78 \%(21 / 23)$ of the bovines' and goats' isolates, respectively $(\mathrm{p}=0.0000)$. There was no pattern observed in the frequency of the virulence factors by geographical area. The SEs genes most frequently detected were seg $(25.33 \%)$, seh $(18 \%)$, sei $(13.33 \%)$, sed $(10.67 \%)$, sec $(7.33 \%)$, sea $(6.67 \%)$ and $s e b$, which was present in only one strain $(0.67 \%)$.

$S$. aureus strains isolated from goats had a statistically significant higher frequency of sea, seg and sei than bovines' isolates (Table 3). The sec and the seh genes were detected exclusively in goats' and bovines' isolates, respectively. The sec gene was most frequently found in isolates from goats raised in the Sertão region ( $\mathrm{p}=0.0061)$; while the smallest frequency of the seh gene was detected in bovines isolates from the Atlantic forest ( $p=0.0206$ ) (Table 3). Goats' isolates had a higher frequency of the SEs genes than bovines $(p=0.0005)$. The sea $(\mathrm{p}=0.0011)$, seb $(\mathrm{p}=0.0007)$, sec $(\mathrm{p}=0.0040)$ and seh $(p=0.0000)$ genes were more frequently found in cap $8(+)$ strains (Table 4). The tsst gene was exclusively detected in goats' isolates (5.33\%) (Table 3 ), and cap5 (+) strains had the lowest frequency of this gene $(1.89 \%, \mathrm{p}=0.0115)$ (Table 4$)$.

The hla and $h l b$ genes were detected in 132 (88\%) and 128 strains (85.33\%), respectively. Both genes were more frequent in bovine isolates than in goats isolates $(95.93 \%$, $\mathrm{p}=0.0000$ and $93.5 \%, \mathrm{p}=0.0000$ respectively), and less frequent in strains isolated from animals raised in the Agreste region (78\%, $\mathrm{p}=0.0233$ and $72 \%, \mathrm{p}=0.0042)$ (Table 3). Strains that did not carry neither cap5 nor cap8 genes had the lowest frequency of $h l a$ and $h l b$ genes (58.82\%, $=0.0000$ and $55.88 \%$, $\mathrm{p}=0.0000$ ) (Table 4).

The capsular gene most frequently detected among the isolated strains was cap $5(70.67 \%)$, while cap 8 was detected in only ten strains $(6.67 \%)$. The cap 5 gene was more frequently found in bovines isolates $(81.3 \%, \mathrm{p}=0.0000)$ and in samples from animals raised in the Agreste region (87.72\%, $\mathrm{p}=0.0002)$ (Table 3).

\section{DISCUSSION}

Staphylococcus aureus has been detected in $10.2 \%$ of cows diagnosed with mastitis and $17.5 \%$ of cows with subclinical mastitis in the state of São Paulo, Brazil (Silva et al. 2013, Rall et al. 2014). S. aureus has also been identified in $16.2 \%$ of sheep and goats from the states of Pernambuco and Bahia, Brazil, (Peixoto et al. 2010) and in 2.72\% of samples from lactating goats from the state of Paraíba, Brazil (Ferreira et al. 2014). The results of the present study corroborates with previous claims that $S$. aureus is one of the main pathogens that causes mastitis in small and large ruminants (Mota et al. 2012).

The see gene was not present in any of the strains evaluated in the study. This gene is carried by a defective phage, and sea and see have 84\% nucleotide homology (Couch et al. 1988). In Italy, studies have shown a low frequency of the see gene in mastitis-related strains (Zecconi et al. 2006) and have not identified the see gene in S. aureus isolated from milk or dairy products (Carfora et al. 2015) similarly to what have been reported in Brazil (Ferreira et al. 2014).

Intramammary infections caused by $S$. aureus may represent a potential risk for human health not only by the risk of pathogen transmission but also by the presence of enterotoxins in milk or dairy products, especially in goats' 
Table 3. Absolute and relative frequency of virulence factors in relation to species and regions of origin

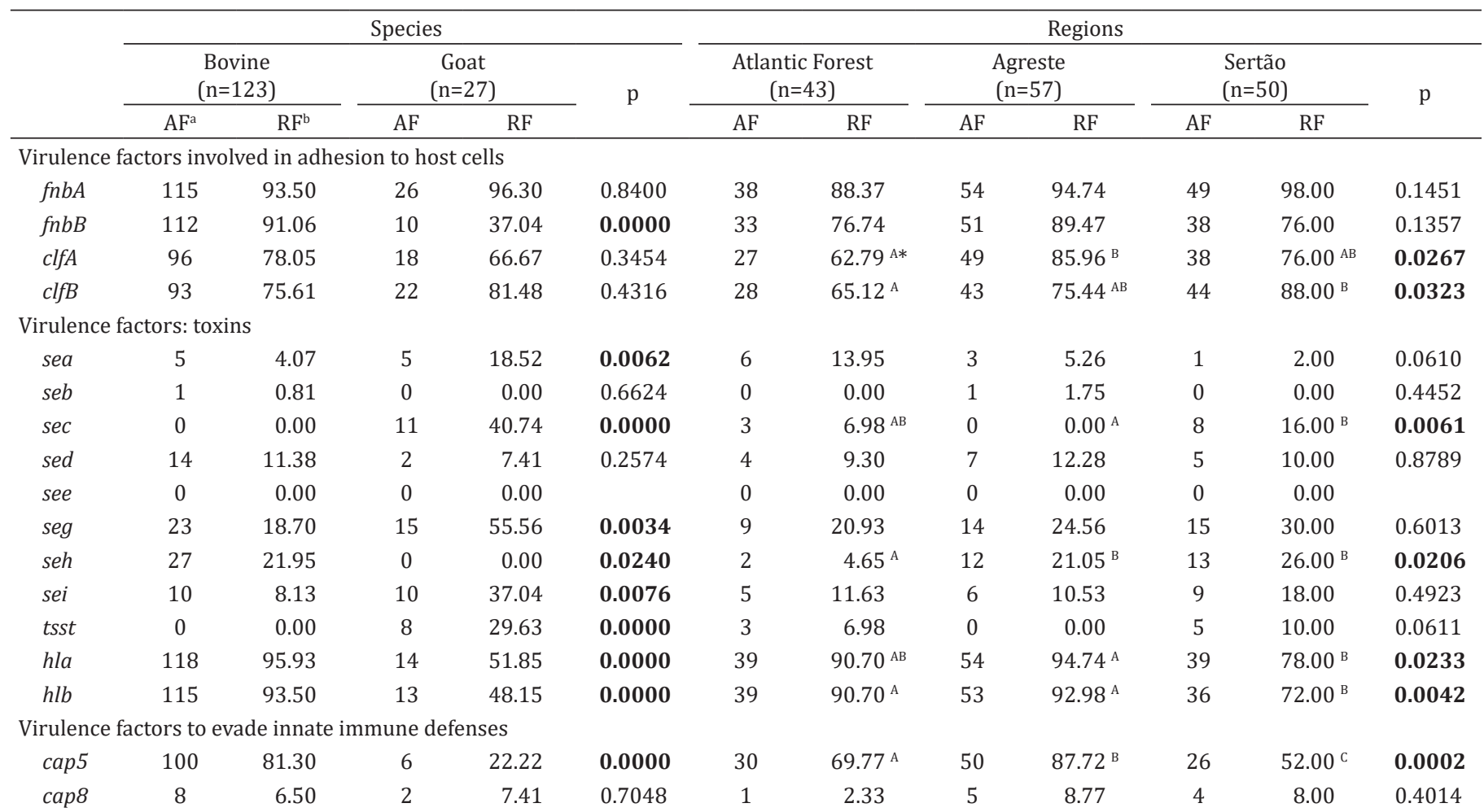

${ }^{\mathrm{a}}$ Absolute frequency, ${ }^{\mathrm{b}}$ relative frequency, ${ }^{\mathrm{A}, \mathrm{B}, \mathrm{C}}$ relative frequency followed by the same capital letters on the lines do not differ significantly; statistical significance $\mathrm{p}<0.05$.

Table 4. Absolute and relative frequency of virulence factors in relation to capsular genotyping

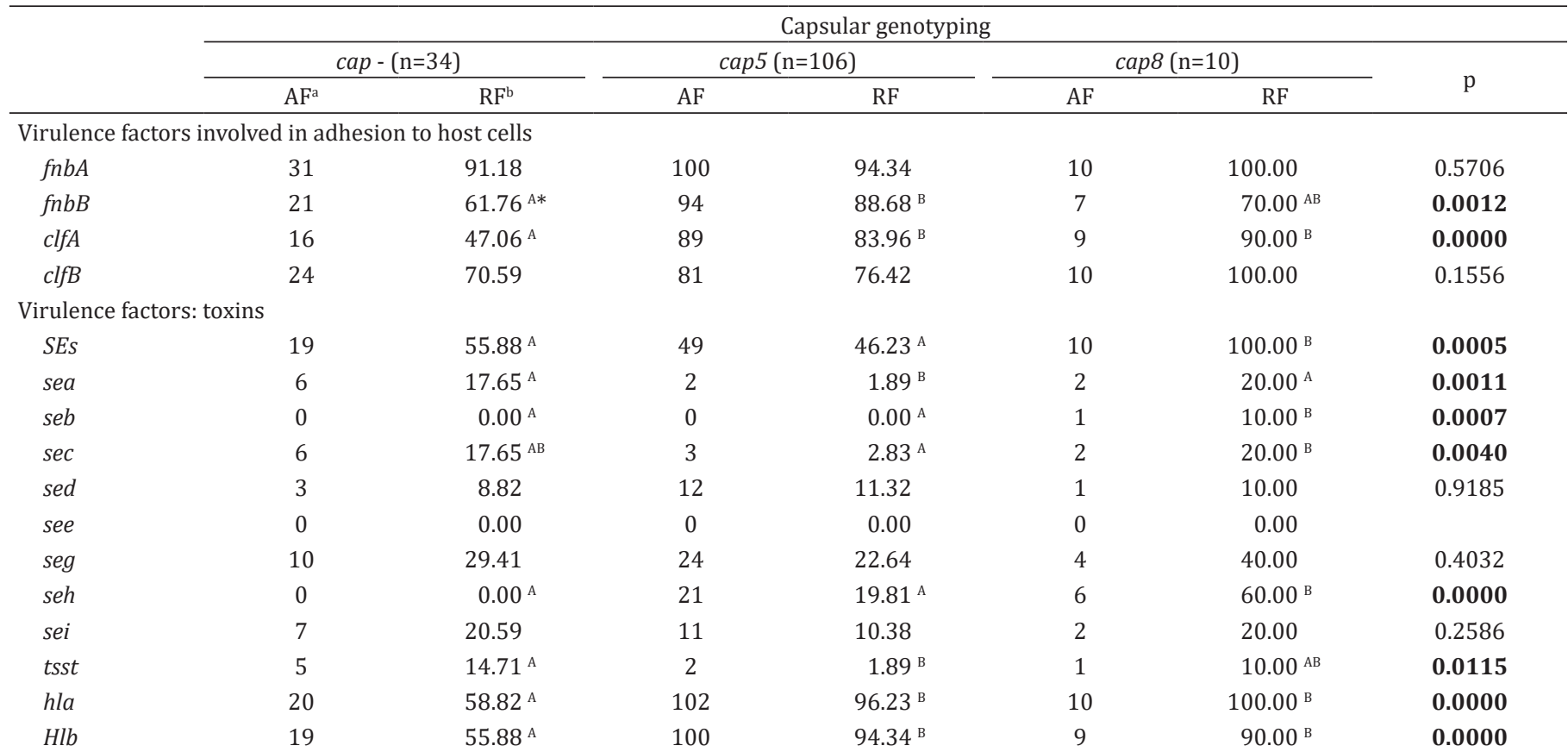

${ }^{\mathrm{a}}$ Absolute frequency, ${ }^{\mathrm{b}}$ relative frequency, ${ }^{\mathrm{A}, \mathrm{B}}$ relative frequency followed by the same capital letters on the lines do not differ significantly; statistical significance $\mathrm{p}<0.05$.

milk. Considering the high frequency of enterotoxin genes found in the present study and the fact that in Brazil the production of artisanal cheese with unpasteurized milk is a common practice (Shinohara et al. 2015), S. aureus infection can pose a threat to public health in the country.
SEs genes have different genetic structures, most of which are mobile genetic elements. These genes can be located in chromosomes, plasmids, pathogenicity islands and phages (Guimarães et al. 2013). The enterotoxins encoded by pathogenicity islands support the hypothesis that they 
could play an important role in the evolution of $S$. aureus as a pathogen (Omoe et al. 2003), but their role in mastitis pathogenesis is still to be elucidated (Piccinini et al. 2010).

Staphylococcal enterotoxins and TSST-1 may act as super antigens for cells of the bovine immune system (Farahmand-Azar et al. 2016). These super antigenic toxins play an important role in modulating the host immune response and may therefore contribute to maintain a suitable environment for colonization (Omoe et al. 2003).

Yadav et al. (2015) reported high frequencies of hla (93.75\%) and $h l b$ genes $(81.25 \%)$ in bovines isolates. The pathogenicity of $S$. aureus is related to the production of a wide variety of exoproteins including alpha and beta hemolysins that contribute to its ability to cause diseases in different mammalian species (Silva et al. 2005).

It is known that IMI caused by $S$. aureus have different patterns in different herds, which vary according to the bacterial strain, geographic location, as well as host- and tissue-related characteristics (Gilot \& Van Leeuwen 2004, Van Leeuwen et al. 2005, Zecconi et al. 2005).

Capsular polysaccharides are important virulence factors of $S$. aureus because they confer resistance to phagocytosis (Sutra et al. 1990) and prolong the pathogen persistence in the host blood stream (O'Riordan \& Lee 2004). However, Tuchscherr et al. (2005) hypothesized that the lack of capsule expression might permit intracellular persistence of $S$. aureus and promote subclinical mammary gland infection.

The distribution of the different cap genotypes of $S$. aureus around the world may differ (Ote et al. 2011, Gogoi-Tiwari et al. 2015). The CP serotype 5 (CP5) or 8 (CP8) are the target of conjugate vaccines. Therefore, it is important to know their prevalence in our geographic regions.

A characterization of $87 \mathrm{~S}$. aureus strains from individual animals of 23 farms located in six different municipal districts of two geographical regions of the state of São Paulo found cap5 and cap8 in 11 (12.64\%) and 76 (87.36\%) strains, respectively (Cabral et al. 2004). Similar results were found in a molecular characterization of $S$. aureus strains isolated from small and large ruminants in 12 regions of France, Brazil, USA, and Belgium, which showed that the cap8 gene was predominant and accounted for $65.4 \%$ of $S$. aureus strains, while cap5 and the non-typeable CP types accounted for $30.7 \%$ and $3.9 \%$, respectively. When considering the host species, cap8 was predominant in small ruminants, with an overall prevalence of $83.1 \%$ in ovine-caprine isolates. In contrast, cap5 was slightly predominant in bovine isolates (56.3\%) (Alves et al. 2009).

In our study, 34 (22.67\%) strains did not carry neither cap5 nor cap8 genes. $S$. aureus strains that do not express capsule induce chronic mastitis in mice, suggesting that the absence of capsule synthesis may help the bacteria to persist in the mammary glands (Tuchscherr et al. 2005).

The existence of two groups of $S$. aureus strains isolated from bovine mastitis based on capsular typing, intracellular survival and agr-typing was confirmed by Bardiau et al. (2016). They hypothesized that the first group "cap5-agrI" may correspond to strains adapted to the intracellular niche leading to chronic infection and that the second group "cap8-agrII" may correspond to strains better adapted to the extracellular niche leading to acute infection. The existence of these two groups is highly important as they may represent two clusters that are adapted differently to the host and/or the surrounding environment (Bardiau et al. 2016).

\section{CONCLUSIONS}

According to the results obtained in the present study, Staphylococcus aureus strains isolated from goats are more toxic than those isolated from bovines.

Our data also show that the cap5 genotype is predominant in both bovines' and goats' isolates.

The cap 8 genotype is likely more virulent due to the number of virulence genes per strain.

Acknowledgements.- This study was financially supported by the Pernambuco Research and Technology Foundation (FACEPE; grant number IBP-0439-5.05/12) and the National Council for Scientific and Technological Development (CNPq; grant number: 442746/2014-8).

\section{REFERENCES}

Alves P.D.D., McCulloch J.A., Even S., Le Maréchal C., Thierry A., Grosset N., Azevedo V., Rosa C.A., Vautor E. \& Le Loir Y. 2009. Molecular characterisation of Staphylococcus aureus strains isolated from small and large ruminants reveals a host rather than tissue specificity. Vet. Microbiol. 137(1-2):190195. <http://dx.doi.org/10.1016/j.vetmic.2008.12.014><PMid:19157725>

Bar D., Tauer L.W., Bennett G., González R.N., Hertl J.A., Schukken Y.H., Schulte H.F., Welcome F.L. \& Gröhn Y.T. 2008. The cost of generic clinical mastitis in dairy cows as estimated by using dynamic programming. J. Dairy Sci. 91(6):2205-2214. <http://dx.doi.org/10.3168/jds.2007-0573> <PMid:18487643>

Bardiau M., Detilleux J., Farnir F., Mainil J.G. \& Ote I. 2014. Associations between properties linked with persistence in a collection of Staphylococcus aureus isolates from bovine mastitis. Vet. Microbiol. 169(1/2):74-79. <http:// dx.doi.org/10.1016/j.vetmic.2013.12.010><PMid:24444863>

Bardiau M., Caplin J., Detilleux J., Graber H., Moroni P., Taminiau B. \& Mainil J.G. 2016. Existence of two groups of Staphylococcus aureus strains isolated from bovine mastitis based on biofilm formation, intracellular survival, capsular profile and agr-typing. Vet. Microbiol. 185:1-6. <http://dx.doi. org/10.1016/j.vetmic.2016.01.003> <PMid:26931384>

Barkema H.W., Schukken Y.H. \& Zadoks R.N. 2006. Invited review: The role of cow, pathogen, and treatment regimen in the therapeutic success of bovine Staphylococcus aureus mastitis. J. Dairy Sci. 89(6):1877-1895. <http:// dx.doi.org/10.3168/jds.S0022-0302(06)72256-1> <PMid:16702252>

Bergonier D., De Crémoux R., Rupp R., Lagriffoul G. \& Berthelot X. 2003. Mastitis of dairy small ruminants. Vet. Res. 34(5):689-716. <http://dx.doi. org/10.1051/vetres:2003030> <PMid:14556701>

Berube B.J. \& Wardenburg J.B. 2013. Staphylococcus aureus $\alpha$-toxin: nearly a century of intrigue. Toxins 5(6):1140-1166. <http://dx.doi.org/10.3390/ toxins5061140><PMid:23888516>

Brakstad O., Aasbakk K. \& Maeland J.A. 1992. Detection of Staphylococcus aureus by polymerase chain reaction amplification of the nuc gene. J. Clin. Microbiol. 30(7):1654-1660. <PMid:1629319>

Cabral K., Lämmler C., Zschöck M., Langoni H., De Sá M.E.P., Victória C. \& Da Silva A. 2004. Pheno and genotyping of Staphylococcus aureus, isolated from bovine milk samples from São Paulo State, Brazil. Can. J. Microbiol. 50(11):901-909. <http://dx.doi.org/10.1139/w04-082><PMid:15644907>

Carfora V., Caprioli A., Marri N., Sagrafoli D., Boselli C., Giacinti G., Giangolini G., Sorbara L., Dottarelli S., Battisti A. \& Amatiste S. 2015. Enterotoxin genes, enterotoxin production, and methicillin resistance in Staphylococcus aureus isolated from milk and dairy products in Central Italy. Int. Dairy J. 42:12-15. <http://dx.doi.org/10.1016/j.idairyj.2014.10.009> 
Couch J.L., Soltis M.T. \& Betley M.J. 1988. Cloning and nucleotide sequence of the type E staphylococcal enterotoxin gene. J. Bacteriol. 170(7):2954-2960. <http://dx.doi.org/10.1128/jb.170.7.2954-2960.1988><PMid:3384800>

Farahmand-Azar S., Ahmadi M., Dastmalchi Saei H. \& Anassori E. 2016. Identification of Toxic Shock Syndrome Toxin-1 (TSST-1) gene in Staphylococcus aureus isolated from bovine mastitis milk. Arch. Razi Inst. 68:17-22.

Ferreira D.H., Carvalho M.G.X., Nardelli M.J., Sousa F.G. \& Oliveira C.J. 2014. Occurrence of enterotoxin-encoding genes in Staphylococcus aureus causing mastitis in lactating goats. Pesq. Vet. Bras. 34(7):633-636. <http://dx.doi. org/10.1590/S0100-736X2014000700004>

Garzoni C. \& Kelley W.L. 2009. Staphylococcus aureus: new evidence for intracellular persistence. Trends Microbiol. 17(2):59-65. <http://dx.doi. org/10.1016/j.tim.2008.11.005><PMid:19208480>

Gilot P. \& Van Leeuwen W. 2004. Comparative analysis of agr locus diversification and overall genetic variability among bovine and human Staphylococcus aureus isolates. J. Clin. Microbiol. 42(3):1265-1269. <http://dx.doi. org/10.1128/JCM.42.3.1265-1269.2004><PMid:15004090>

Gogoi-Tiwari J., Babra Waryah C., Sunagar R., Veeresh H.B., Nuthanalakshmi V., Preethirani P.L., Sharada R., Isloor S., Bhat A., Al-Salami H., Hegde N.R. \& Mukkur T.K. 2015. Typing of Staphylococcus aureus isolated from bovine mastitis cases in Australia and India. Aust. Vet. J. 93(8):278-282. <http:// dx.doi.org/10.1111/avj.12349><PMid:26220320>

Guimarães F.F., Nóbrega D.B., Richini-Pereira V.B., Marson P.M., Figueiredo Pantoja J.C. \& Langoni H. 2013. Enterotoxin genes in coagulase-negative and coagulase-positive staphylococci isolated from bovine milk. J. Dairy Sci. 96(5):2866-2872. <http://dx.doi.org/10.3168/jds.2012-5864> <PMid:23477822>

Halasa T., Huijps K., Østerås O. \& Hogeveen H. 2007. Economic effects of bovine mastitis and mastitis management: a review. Vet. Quart. 29(1):18-31. <http://dx.doi.org/10.1080/01652176.2007.9695224><PMid:17471788>

Hall T.A. 1999. BioEdit: a user-friendly biological sequence alignment editor and analysis program for Windows 95/98/NT. Nucl. Acids Symp. Ser. 41:95-98.

Hiitiö H., Riva R., Autio T., Pohjanvirta T., Holopainen J., Pyörälä S. \& Pelkonen S. 2015. Performance of a real-time PCR assay in routine bovine mastitis diagnostics compared with in-depth conventional culture. J. Dairy Res. 82(2):200-208. <http://dx.doi.org/10.1017/S0022029915000084> $<$ PMid:25704849>

Kerro D.O., Van Dijk J. \& Nederbragt H. 2002. Factors involved in the early pathogenesis of bovine Staphylococcus aureus mastitis with emphasis on bacterial adhesion and invasion. a review. Vet. Quart. 24(4):181-198. <http://dx.doi.org/10.1080/01652176.2002.9695135><PMid:12540135>

Mehrotra M., Wang G. \& Johnson W.M. 2000. Multiplex PCR for detection of genes for Staphylococcus aureus enterotoxins, exfoliative toxins, toxic shock syndrome toxin 1 , and methicillin resistance. J. Clin. Microbiol. 38(3):1032-1035. <PMid:10698991>

Mota R.A., Medeiros E.S., Santos M.V., Pinheiro Júnior J.W., Moura A.P.B. \& Coutinho L.C.A. 2012. Participação dos Staphylococcus spp. na etiologia das mastites em bovinos leiteiros no Estado de Pernambuco (Brasil). Ciênc. Anim. Bras. 13(1):124-130. <http://dx.doi.org/10.5216/cab.v13i1.3790>

National-Mastitis-Council 1999. Laboratory and field handbook on bovine mastitis. National Mastitis Council Madison, WI. 222p.

Ní Eidhin D., Perkins S., Francois P., Vaudaux P., Höök M. \& Foster T.J. 1998. Clumping factor B (ClfB), a new surface-located fibrinogen-binding adhesin of Staphylococcus aureus. Mol. Microbiol. 30(2):245-257. <http://dx.doi. org/10.1046/j.1365-2958.1998.01050.x><PMid:9791170>

Nóbrega R.S., Farias R. \& Santos C. 2015. Variabilidade temporal e espacial da precipitação pluviométrica em Pernambuco através de índices de extremos climáticos. Revta Bras. Meteorol. 30(2):171-180.<http://dx.doi. org/10.1590/0102-778620130624>
O'Riordan K. \& Lee J.C. 2004. Staphylococcus aureus capsular polysaccharides. Clin. Microbiol. Rev. 17(1):218-234. <http://dx.doi.org/10.1128/ CMR.17.1.218-234.2004><PMid:14726462>

Omoe K., Hu D.-L., Takahashi-Omoe H., Nakane A. \& Shinagawa K. 2003. Identification and characterization of a new staphylococcal enterotoxinrelated putative toxin encoded by two kinds of plasmids. Infect. Immun. 71(10):6088-6094. <http://dx.doi.org/10.1128/IAI.71.10.6088-6094.2003> $<$ PMid:14500536>

Ote I., Taminiau B., Duprez J.-N., Dizier I. \& Mainil J.G. 2011. Genotypic characterization by polymerase chain reaction of Staphylococcus aureus isolates associated with bovine mastitis. Vet. Microbiol. 153(3-4):285-292. <http://dx.doi.org/10.1016/j.vetmic.2011.05.042><PMid:21708435>

Pantoja J.C.F., Hulland C. \& Ruegg P. 2009. Somatic cell count status across the dry period as a risk factor for the development of clinical mastitis in the subsequent lactation. J. Dairy Sci. 92(1):139-148. <http://dx.doi. org/10.3168/jds.2008-1477><PMid:19109272>

Peixoto R.M., França C.A., Souza Júnior A.F., Veschi J.L.A. \& Costa M.M. 2010. Etiologia e perfil de sensibilidade antimicrobiana dos isolados bacterianos da mastite em pequenos ruminantes e concordância de técnicas empregadas no diagnóstico. Pesq. Vet. Bras. 30(9):735-740.<http://dx.doi.org/10.1590/ S0100-736X2010000900005>

Piccinini R., Borromeo V. \& Zecconi A. 2010. Relationship between S. aureus gene pattern and dairy herd mastitis prevalence. Vet. Microbiol. 145(1-2):100105. <http://dx.doi.org/10.1016/j.vetmic.2010.03.005><PMid:20413230>

Rall V.L.M., Miranda E.S., Castilho I.G., Camargo C.H., Langoni H., Guimarães F.F, Araújo Júnior J.P. \& Fernandes Júnior A. 2014. Diversity of Staphylococcus species and prevalence of enterotoxin genes isolated from milk of healthy cows and cows with subclinical mastitis. J. Dairy Sci. 97(2):829-837. <http:// dx.doi.org/10.3168/jds.2013-7226><PMid:24359821>

Roberson J., Fox L., Hancock D., Gay J. \& Besser T. 1998. Sources of intramammary infections from Staphylococcus aureus in dairy heifers at first parturition. J. Dairy Sci. 81(3):687-693. <http://dx.doi.org/10.3168/ jds.S0022-0302(98)75624-3><PMid:9565871>

Sabat A., Krzyszton-Russjan J., Strzalka W., Filipek R., Kosowska K., Hryniewicz W., Travis J. \& Potempa J. 2003. New method for typing Staphylococcus aureus strains: multiple-locus variable-number tandem repeat analysis of polymorphism and genetic relationships of clinical isolates. J. Clin. Microbiol. 41(4):1801-1804.<http://dx.doi.org/10.1128/JCM.41.4.18011804.2003><PMid:12682193>

Schalm O. \& Noorlander D. 1957. Experiments and observations leading to development of the California mastitis test. J. Am. Vet. Med. Assoc. 130(5):199-204. <PMid:13416088>

Shinohara N.K.S., Santos M.C.G., Medeiros S.T.C., Padilha M.R.D.F. \& Matsumoto M. 2015. Cultural importance of cheese type for kingdom pernambucano. Holos 1:62-71. <http://dx.doi.org/10.15628/holos.2015.2488>

Silva E.R., Boechat J.U.D., Martins J.C.D., Ferreira W.P.B., Siqueira A.P. \& Silva N. 2005. Hemolysin production by Staphylococcus aureus species isolated from mastitic goat milk in Brazilian dairy herds. Small Rumin. Res. 56(1/3):271275. <http://dx.doi.org/10.1016/j.smallrumres.2004.04.011>

Silva N., Guimarães F., Manzi M., Budri P., Gómez-Sanz E., Benito D., Langoni H., Rall V. \& Torres C. 2013. Molecular characterization and clonal diversity of methicillin-susceptible Staphylococcus aureus in milk of cows with mastitis in Brazil. J. Dairy Sci. 96(11):6856-6862. <http://dx.doi.org/10.3168/ jds.2013-6719><PMid:24054305>

Sutra L., Rainard P. \& Poutrel B. 1990. Phagocytosis of mastitis isolates of Staphylococcus aureus and expression of type 5 capsular polysaccharide are influenced by growth in the presence of milk. J. Clin. Microbiol. 28(10):2253-2258. <PMid:2229349>

Tuchscherr L.P.N., Buzzola F.R., Alvarez L.P., Caccuri R.L., Lee J.C. \& Sordelli D.0. 2005. Capsule-negative Staphylococcus aureus induces chronic experimental mastitis in mice. Infect. Immun. 73(12):7932-7937.<http:// dx.doi.org/10.1128/IAI.73.12.7932-7937.2005><PMid:16299284> 
Van Leeuwen W.B., Melles D.C., Alaidan A., Al-Ahdal M., Boelens H.A., Snijders S.V., Wertheim H., Van Duijkeren E., Peeters J.K., Van der Spek P.J., Gorkink R., Simons G., Verbrugh H.A. \& Van Belkum A. 2005. Host- and tissue-specific pathogenic traits of Staphylococcus aureus. J. Bacteriol. 187(13):4584-4591. <http://dx.doi.org/10.1128/JB.187.13.4584-4591.2005><PMid:15968069>

Yadav J., Bhati T. \& Kataria A.K. 2015. Phenotypic and genotypic haemolysin properties of Staphylococcus aureus obtained from milk of cattle and buffalo with clinical mastitis. J. Pure Appl. Microbiol. 9:349-355.
Zecconi A., Binda E., Borromeo V. \& Piccinini R. 2005. Relationship between some Staphylococcus aureus pathogenic factors and growth rates and somatic cell counts. J. Dairy Res. 72(2):203-208. <http://dx.doi.org/10.1017/ S0022029905000841> <PMid:15909686>

Zecconi A., Cesaris L., Liandris E., Daprà V. \& Piccinini R. 2006. Role of several Staphylococcus aureus virulence factors on the inflammatory response in bovine mammary gland. Microb. Pathogenesis 40(4):177-183. <http:// dx.doi.org/10.1016/j.micpath.2006.01.001><PMid:16517115> 